\title{
Variation of Soil Microbial Growth and Enzyme Activities by Application of Treated Distillery Effluent in Maize Crop Grown Under Sandy Loam Soils
}

\author{
Dhakshanamoorthy Dinesh ${ }^{1 *}$, Lakshmanan Chithra ${ }^{2}$, Murugaiyan Baskar, \\ Karuppusamy Rajan ${ }^{4}$, Kandasamy Senthilraja ${ }^{5}$, Mariappan Sankar ${ }^{6}$, \\ Raj Kumar ${ }^{1}$ and Karthikeyan Sivakumar ${ }^{7}$ \\ ${ }^{1}$ ICAR - Indian Institute of Soil and Water Conservation, Research Centre, \\ Vasad, District Anand -388306, India \\ ${ }^{2}$ TRRI, TNAU, Aduthurai, Tamil Nadu, India \\ ${ }^{3}$ ADAC\&RI, TNAU, Tiruchirappalli, Tamil Nadu, India \\ ${ }^{4}$ ICAR - Indian Institute of Soil and Water Conservation, Research Centre, \\ Udhagamandalam, Tamil Nadu, India \\ ${ }^{5}$ Department of Environmental Sciences, TNAU, Coimbatore, Tamil Nadu, India \\ ${ }^{6}$ ICAR - Indian Institute of Soil and Water Conservation, Dehradun, Uttarakhand, India \\ ${ }^{7}$ FC\&RI, TNAU, Mettupalayam, Tamil Nadu, India \\ *Corresponding author
}

\begin{tabular}{|l|}
\hline K e y w o r d s \\
$\begin{array}{l}\text { Treated distillery } \\
\text { effluent, Bio } \\
\text { compost, FYM, Soil } \\
\text { microbial } \\
\text { population, Maize. }\end{array}$ \\
\hline Article Info \\
\hline $\begin{array}{l}\text { Accepted: } \\
\text { 12 October } 2017 \\
\text { Available Online: } \\
\text { 10 December } 2017\end{array}$ \\
\hline
\end{tabular}

Keywords

Treated distillery effluent, Bio compost, FYM, Soil microbial population, Maize.

12 October 2017 10 December 2017

\section{A B S T R A C T}

A field experiment was conducted to investigate the soil microbial growth and enzymatic activity of Treated Distillery Effluent (TDE) and Bio-compost (BC) applied in sandy loam soils grown with Maize crop (Zea mays). Under split plot design with five main plots with addition of organics viz., No organics; application of TDE @ 0.5 lakh litres $\mathrm{ha}^{-1}$; TDE@1.0 lakh litres ha ${ }^{-1}$; Bio compost @ $5 \mathrm{t} \mathrm{ha}^{-1}$ and FYM @ $12.5 \mathrm{t} \mathrm{ha}^{-1}+$ biofertilizers. In addition, five subplot treatments viz., addition of inorganic fertilizers at different levels of recommended dose of NP fertilizers $(0 \%, 50 \%, 75 \%$ and $100 \%)$ compared with 100 per cent recommended dose of NPK @ $150: 75: 75$ of $\mathrm{kg} \mathrm{N}, \mathrm{P}_{2} \mathrm{O}_{5}$ and $\mathrm{K}_{2} \mathrm{O}$ ha $^{-1}$. Application of TDE 1.0 lakh litres ha ${ }^{-1}$ resulted higher bacterial, fungal and actinomycetes population over control at all stages of crop growth. Indeed, the soil bacterial population recorded the highest value of 20.1 and $19.3 \times 10^{6} \mathrm{CFU} \mathrm{g}^{-1}$ of soil with the application of TDE @ 1.0 lakh litres ha ${ }^{-1}$ compared to control at post-harvest stage. There was an increase in the soil fungal population to the tune of 30.3 per cent over control at post-harvest stage. Furthermore, application of TDE @ 1.0 lakh litres ha ${ }^{-1}$ recorded the highest soil actinomycetes population at all stages of crop growth. The soil enzyme activities as phosphatase, dehydrogenase and urease recorded the highest values of $12.8 \mu \mathrm{g}$ p-nitrophenol g ${ }^{-1}$ soil hr ${ }^{-1} ; 2.96 \mu \mathrm{g} \mathrm{TPF} \mathrm{g}^{-1}$ soil hr ${ }^{-1}$ and $5.16 \mu \mathrm{g} \mathrm{NH}_{4}-\mathrm{N} \mathrm{g}^{-1}$ soil hr ${ }^{-1}$ respectively with the application of TDE @ 1.0 lakh litres ha $^{-1}$. The soil microbial population and enzyme activities increased with the application of distillery effluent over control. Hence, it was observed that, Soil microbial activity had a direct impact on the plant nutrient availability as well as other favorable properties associated with soil productivity. 


\section{Introduction}

A typical sugar and distillery complex generates large quantities of solid and liquid wastes like bagasse (the fibre residue of sugar cane), press mud (filter cake), molasses and distillery effluent or spent wash. However, some of these wastes are recycled for agricultural production mainly for irrigation and nutrients need of crops. Presently the distillery industrial wastes, which are considered unusable, have found to be useful in support of sustainable agriculture. There are 319 distilleries in India with an installed capacity of 3.25 billion litres of alcohol and generating 48 billion litres of distillery effluent annually (Uppal, 2004). In general, the treated effluent contains the considerable amount of $\mathrm{N}$ and $\mathrm{P}$, rich in $\mathrm{K}, \mathrm{Ca}, \mathrm{Mg}$ and $\mathrm{S}$ and the trace amount of $\mathrm{Zn}, \mathrm{Cu}, \mathrm{Fe}$ and $\mathrm{Mn}$ (Mohamed Haroon and Subash Chandra Bose, 2004). However, the annual treated distillery effluent obtained in India can supply 16,800 tonnes of $\mathrm{N}, 6,300$ tonnes of $\mathrm{P}$ and $1,26,000$ tonnes $\mathrm{K}$ and by which it is estimated that the Indian distilleries could contribute about 10,000 million rupees annually as plant nutrients. The distillery effluent after treatment ( $\mathrm{pH}$ correction and BOD reduction) can be a good source of irrigation water around the distillery industries. Hence, land disposal of treated distillery effluent with proper management technologies could also be thought of as an alternative, especially in agriculture to improve crop productivity. It has been also noticed that application of distillery effluent in acid soil is not observing for any change that affects the soil quality (Das et al., 2010). Since the distillery effluent contains more amounts of organic and inorganic nutrients, this could be used as fertilizer for refining crop growth and soil fertility (Suganya et al., 2002; Joshi et al., 2000). The treated distillery effluent improves the soil biological and biochemical activities. Application of distillery effluent at the rate of
$250 \mathrm{~m}^{3} \mathrm{ha}^{-1}$ pretends the growth of soil microorganisms (Batchs et al., 1993). High organic matter even with high BOD and nutrients in the distillery effluent improves the enzyme activities, such as dehydrogenases, urease and phosphatase even without treatment in dryland areas with the application of $125 \mathrm{~m}^{3}$ $\mathrm{ha}^{-1}$ (Murugaragavan, 2002). The treated distillery effluent with reduced BOD has also improved the activities of dehydrogenase, urease and phosphatase in treated soil (Nandakumar, 2009). In order to harness its full manurial potential, there is an endorsement of one-time land application of distillery effluent as a source of plant nutrients (Baskar et. al., 2003)

Maize (Zea mays L.) is one of the third most important cereals, next to wheat and rice in the world as well as in India. It is a significance source of a large number of industrial products besides its uses as human food and animal feed. In India, maize is cultivated on 8.11 million hectares with a production of 19.77 million tonnes and the average yield is $2,435 \mathrm{~kg} \mathrm{ha}^{-1}$ in 2007-08 (DMR, 2008). In India, at present, about 35 per cent of the maize produced in the country is used for human consumption, 25 per cent each in poultry feed and cattle feed and 15 per cent in food processing (corn flakes, popcorn, etc.) and other industries (mainly starch, dextrose, corn syrup, corn oil, etc.,).

By 2020, the necessity of maize for various sectors will be around 100 million tonnes, of which poultry sector needs 31 million tonnes. Hence it could be a hard task for us to rise the maize production from the current level of 34 to 100 million tonnes (Seshaiah, 2000). Tamil Nadu is one of the non-traditional areas for maize cultivation. Currently in Tamil Nadu, maize is cultivated in an area of 287 thousand hectares with a productivity of $4.40 \mathrm{t} \mathrm{ha}^{-1}$ which is much higher than the national (Anon, 2010). 
Keeping the above facts in view, the current study was aimed to find out the utilisation of treated distillery effluent viz., the Treated Distillery Effluent (TDE) and Bio-compost (BC) for maize crop production and to study the soil microbial population and enzymatic activity of TDE, bio-compost and FYM applied soils.

\section{Materials and Methods}

A field experiment was conducted in Vilapakkam village of Vellore district, Tamil Nadu. The Soil of the study area belongs to Eathapur series which is a sandy loam soils, fine loamy hyperthermic family of Typic Rhodustalfs, Alfisols. The geographical location of the experiment site is $12^{\circ} 51^{\prime} \mathrm{N}$ latitude, $79^{\circ} 18^{\prime} \mathrm{E}$ longitude with an altitude of 246 metre above the mean sea level. The soil is slightly acidic (pH 6.58) and EC of $0.14 \mathrm{dS}$ $\mathrm{m}^{-1}$. The organic carbon content was found to be low $\left(3.90 \mathrm{~g} \mathrm{~kg}^{-1}\right)$. The $\mathrm{KMnO}_{4}-\mathrm{N}(161 \mathrm{~kg}$ $\mathrm{ha}^{-1}$ ) and the $\mathrm{NH}_{4} \mathrm{OAc}-\mathrm{K}\left(78 \mathrm{~kg} \mathrm{ha}^{-1}\right)$ were low and the Olsen-P level was medium $(15 \mathrm{~kg}$ $\mathrm{ha}^{-1}$ ).

The DTPA- Mn (4.04 mg kg-1), Fe (9.67 mg $\left.\mathrm{kg}^{-1}\right)$ and hot water soluble Boron $(0.41 \mathrm{mg}$ $\mathrm{kg}^{-1}$ ) were found to be sufficient in the soil but the availability of DTPA-Zn $(0.75 \mathrm{mg} \mathrm{kg}$ $\left.{ }^{1}\right)$ and DTPA Cu $\left(0.55 \mathrm{mg} \mathrm{kg}^{-1}\right)$ were found to be deficient. The microbial populations of experiment soils were $8.20 \times 10^{6} \mathrm{CFU} \mathrm{g}^{-1}$ of soil for bacteria, $16.3 \times 10^{4} \mathrm{CFU} \mathrm{\textrm {g } ^ { - 1 }}$ of soil for fungi and $3.5 \times 10^{2} \mathrm{CFU} \mathrm{g}^{-1}$ of soil for actinomycetes.

A composite soil sample was collected from the experimental field, and air dried, homogenized, sieved in $2 \mathrm{~mm}$ sieve for analyzing various physical and chemical properties. Fresh soil sample were used for analyzing microbial properties and the results were expressed on oven dry weight basis. The population of different groups of microorganisms' viz., bacteria (Nutrient glucose agar medium), fungi (Martin's rose bengal agar medium) and actinomycetes (Kenknight's agar medium) in the field soils were computed by using standard serial dilution plating techniques (Waksman and Fred, 1922).

\section{Soil enzyme activity}

\section{Dehydrogenase}

Fresh composite soil sample (5 g) was taken in a boiling tube along with $1 \mathrm{ml}$ of 3 per cent 2, 3, 5-Triphenyl tetrazolium chloride and 1 $\mathrm{ml}$ of 1 per cent glucose. Added with $2.5 \mathrm{ml}$ distilled and incubated for 24 hours. After completion of incubation period, $10.0 \mathrm{ml}$ of methanol was added and incubated for another 6 hours. Then, the sample was filtered using Whatman No.1 filter paper. The filtrate obtained was red in colour. The colour was developed then read at $485 \mathrm{~nm}$ and the concentration of dehydrogenase $(\mathrm{X})$ in the sample was acquired from the standard graph drawn by using Tri Phenyl Formazan (TPF) as standard (Chendrayan et al., 1980).

Dehydrogenase activity of the sample ( $\mu \mathrm{g}$ of $\mathrm{TPF} / \mathrm{g})=\mathrm{X} / 5$

\section{Phosphatase}

Five gram (w) of the fresh composite soil was taken in a boiling tube with $10 \mathrm{ml}$ distilled water. Added with $0.25 \mathrm{ml}$ of toluene and 1.0 $\mathrm{ml}$ of p-nitrophenol phosphate (PNPP), it was incubated at room temperature for an hour. Then, $5.0 \mathrm{ml}$ of $0.5 \mathrm{M}$ sodium chloride and 20 $\mathrm{ml}$ of $0.5 \mathrm{M}$ sodium hydroxide were added to the sample and filtered through Whatman No.42 filter paper. The colour intensity was read at $420 \mathrm{~nm}$ and the concentration of phosphatase (X) in the sample was obtained from the standard graph (Tabatabai and Bremner, 1969). 
Phosphatase activity of the sample ( $\mu \mathrm{g}$ of $\mathrm{PNPP} / \mathrm{g})=\mathrm{X} / \mathrm{w}$.

\section{Urease}

Composite soil sample (10 g) of dry and sieved soil was taken in a $100 \mathrm{ml}$ volumetric flask. To this, $1.5 \mathrm{ml}$ of toluene was added, mixed well and incubated for 15 minutes. Then, $10.0 \mathrm{ml}$ of 10 per cent urea solution and $20 \mathrm{ml}$ of citrate buffer were added, mixed thoroughly, stoppered and incubated for $3 \mathrm{~h}$ at $37^{\circ} \mathrm{C}$. Then the volume was made up to 100 $\mathrm{ml}$ with distilled water, mixed by shaking immediately. The contents were filtered through Whatman No. 1 filter paper and 1.0 $\mathrm{ml}$ of filtrate was pipetted out into $50 \mathrm{ml}$ volumetric flask. To this, $9.0 \mathrm{ml}$ of distilled water, $4.0 \mathrm{ml}$ of phenate and $3 \mathrm{ml}$ of $\mathrm{NaOCl}$ were added, mixed well and allowed to stand for 20 minutes. The volume was made up to $50 \mathrm{ml}$ and mixed well. The bluish green colour developed was read at $630 \mathrm{~nm}$. Simultaneously, a blank was also run (without urea solution). The concentration of urease in the sample was obtained from the standard graph using diammonium sulphate (Bremner and Mulvany, 1978).

The soil was ploughed well and the calculated quantities of Treated Distillery Effluent (TDE), (Table 1) Bio-Compost (BC) (Table 2) and Farm Yard Manure (FYM) as per the treatment schedule were applied uniformly to the concerned plots before 30 days of sowing in main plots $(\mathrm{M})$. No organics $\mathrm{M}_{1}$; The onetime application of TDE @ 0.5 and 1.0 lakh litres ha ${ }^{-1}$ was applied in $\mathrm{M}_{2}, \mathrm{M}_{3}$, respectively. Bio compost was prepared by utilizing the pressmud (an organic solid material obtained as by-product from sugar industries) as a raw material and the composting process is being carried out by mechanized open window system with the use of treated distillery spent wash and bioinoculants for about $70-80$ days. The product is then sun-dried ground and sieved by a mechanical separator and then used as bio compost for manurial purpose. The bio-compost @ $5 \mathrm{t} \mathrm{ha}^{-1}$ was spread in $\mathrm{M}_{4}$ and FYM@12.5 t ha ${ }^{-1}$ and Biofertilizers (Azospirillum and Phosphobacteria@ $2.0 \mathrm{~kg}$ $\mathrm{ha}^{-1}$ ) spread in $\mathrm{M}_{5}$. After 30 days, the surface of the treated plots was inverted manually with the spade to facilitate aeration and oxidation. Then, the ridges and furrows were formed as the test crop was Maize (Variety NK 6325) and the fertilizer schedule of 150:75:75 kg N, $\mathrm{P}_{2} \mathrm{O}_{5}, \mathrm{~K}_{2} \mathrm{O}$ ha $^{-1}$ was adopted as 100 per cent recommended dose (TNAU CPG, 2007).

Calculated quantities of fertilizers were applied in each treatment as per the treatment schedule. Entire phosphorus dose was applied as basal while nitrogen and potassium were applied in two splits at 25-30, 45-50 days after sowing. To avoid micro nutrients deficiency, the TNAU micronutrient mixture @ $12.5 \mathrm{~kg} \mathrm{ha}^{-1}$ as enriched with FYM was applied, uniformly. All other cultural practices including gap filling, thinning, weeding and plant protection measures were carried out as per the recommendations of crop production guide of Tamil Nadu Agricultural University.

\section{Treatment details}

\section{Treatments}

\section{Main plots}

M1 - Control

M2* - One-time application of TDE @ 0.5 lakh litres $\mathrm{ha}^{-1}$

M3* - One-time application of TDE @ 1.0 lakh litres $\mathrm{ha}^{-1}$

M4 - Bio- compost @ $5 \mathrm{t} \mathrm{ha}^{-1}$ at last ploughing 
M5 - FYM @12.5 t ha ${ }^{-1}+$ Biofertilizers (Azospirillum and Phosphobacteria each @ $2 \mathrm{~kg}$ $\left.\mathrm{ha}^{-1}\right)$ at last ploughing

(*application at one month before sowing and thoroughly incorporation with soil).

\section{Sub plots}

S1 - Control

$\mathrm{S} 2$ - $50 \%$ recommended dose of $\mathrm{N}$ and $\mathrm{P}_{2} \mathrm{O}_{5}$

$\mathrm{S} 3$ - $75 \%$ recommended dose of $\mathrm{N}$ and $\mathrm{P}_{2} \mathrm{O}_{5}$

S4 - $100 \%$ recommended dose of $\mathrm{N}$ and $\mathrm{P}_{2} \mathrm{O}_{5}$

S5* - 100\% recommended dose of NPK (as per blanket recommendation)

(*100 \% Recommended dose of NPK (150:75:75 kg N, $\mathrm{P}_{2} \mathrm{O}_{5}$ and $\mathrm{K}_{2} \mathrm{O}^{-1}$ )

The data of the experiment were statistically analyzed by adopting appropriate statistical methods as outlined by Gomez and Gomez (1984). The critical differences were calculated at five per cent level of probability.

\section{Results and Discussion}

\section{Soil microbial populations}

\section{Soil bacterial population}

Soil bacterial population recorded at different stages of crop growth under various treatments ranged from 16.1 to $35.9 \times 10^{6}$ CFU $\mathrm{g}^{-1}$ of soil. Application of TDE and organic manures significantly increased the soil bacterial population at all the stages of observation. Among the main plot treatments, the highest mean value of the bacterial population ranged from 29.4 to $35.2 \times 10^{6}$ CFU g ${ }^{-1}$ of soil, Application of FYM @ $12.5 \mathrm{t}$ $\mathrm{ha}^{-1}+$ biofertilizers recorded more bacterial population than all other treatments at vegetative stage, while at flowering and postharvest stage, the application of TDE @ 1.0 lakh litres $\mathrm{ha}^{-1}$ recorded higher bacterial population than all other treatments.

Among the subplots treatments, no significant differences were noticed in bacterial population at all the stages. The interaction effect of $\mathrm{M} \times \mathrm{S}$ treatment was significant for the application of TDE and organic manures along with the different doses of NPK fertilizers. Application of TDE @ 1.0 lakh litres ha ${ }^{-1}$ along with application of 75 per cent RD of NP fertilizer had recorded the higher bacterial population which was on par with $\mathrm{M}_{3} \mathrm{~S}_{4}, \mathrm{M}_{3} \mathrm{~S}_{5}$, $\mathrm{M}_{5} \mathrm{~S}_{4}$ and $\mathrm{M}_{5} \mathrm{~S}_{3}$ at vegetative stage in red sandy loam soil. At flowering and post-harvest stage, application of TDE @ 1.0 lakh litres ha ${ }^{-1}$ along with 100 per cent RD of NPK and 100 per cent $\mathrm{RD}$ of NP as well as 75 per cent RD of NP fertilizers recorded higher bacterial population than control. In general, the bacterial population was higher at flowering stage, compared to vegetative and post-harvest stages.

\section{Soil fungal population}

Soil fungal population monitored at different stages of crop growth under various treatments and it ranged from 7.9 to $16.5 \times$ $10^{4} \mathrm{CFU} \mathrm{g}{ }^{-1}$ of soil. Soil fungal population was significantly influenced by the application of TDE and organic manures at all the stages. Among the main plot treatments, the mean value of fungal population ranged from 11.6 to $15.2 \times 10^{6} \mathrm{CFU} \mathrm{g}{ }^{-1}$ of soil, wherein application of TDE @ 1.0 lakh litres $\mathrm{ha}^{-1}$ recorded the highest fungal population at all the stages.

Among the sub plot treatments, application of 100 per cent recommended dose of NPK recorded higher fungal population which is on par with the application of 100 per cent NP at all the stages, than the rest of the treatments. 
The interaction effect of $\mathrm{M} \times \mathrm{S}$ was also found to be significant. The application of TDE@1.0 lakh litres ha ${ }^{-1}$ along with 100 per cent recommended dose of NPK fertilizers are on par with $\mathrm{M}_{3} \mathrm{~S}_{4}, \mathrm{M}_{3} \mathrm{~S}_{3}, \mathrm{M}_{2} \mathrm{~S}_{3}$ and $\mathrm{M}_{2} \mathrm{~S}_{4}$ at all growth stages except post-harvest stage. At flowering stage, the application of FYM @ $12.5 \mathrm{t} \mathrm{ha}^{-1}+$ Biofertilizers along with 100 per cent NPK fertilizers recorded the highest fungal population which is on par with the treatments of $\mathrm{M}_{5} \mathrm{~S}_{4} \quad \mathrm{M}_{5} \mathrm{~S}_{3}$ and $\mathrm{M}_{3} \mathrm{~S}_{5}$. In general, the fungal population was gradually decreased with the advancement of crop growth.

\section{Soil actinomycetes population}

Actinomycetes population of the soil monitored at different stages of crop growth under various treatments ranged from 3.4 to $9.4 \times 10^{2} \mathrm{CFU} \mathrm{g}^{-1}$ of soil. Application of TDE and organic manures significantly increased the soil actinomycetes population at all the stages of observation. The highest mean value of actinomycetes population ranged from 6.6 to $8.5 \times 10^{2} \mathrm{CFU} \mathrm{g}^{-1}$ of soil in treated soil, where in the treatment which received TDE @ 1.0 lakh litres $\mathrm{ha}^{-1}$, followed by the application FYM @ $12.5 \mathrm{t} \mathrm{ha}^{-1}+$ biofertilizers recording higher actinomycetes population at all the stages of crop growth (Fig. 1).

The impact of organic manures such as biocompost and FYM were found to be on similar under most of the growth stages except vegetative stage in recording higher actinomycetes population than control. Among subplot treatments, application of 100 per cent RD of NPK fertilizer registered the higher Actinomycetes population which is on par with 100 per cent RD of NP fertilizer. The soil actinomycetes population declined with the advancement of crop growth. The Interaction effect on $\mathrm{M} \times \mathrm{S}$ was found to be significant in different treatment combination in most of the growth stages of the crop.
Relatively higher actinomycetes population was recorded in the treatment receiving TDE @ 1.0 lakh litres ha ${ }^{-1}$ along with 100 per cent RD of NPK fertilizer over control and this was comparable with 100 per cent RD of NP fertilizers in most of the growth stages of maize. The actinomycetes population was gradually decreased with advancement of crop growth.

Microbial activity had a direct impact on the plant nutrient availability as well as other properties related to soil productivity. Microbial activity is dependent on adequate energy supply from organic $\mathrm{C}$, inorganic ion availability and numerous environmental conditions. The impact of TDE, bio-compost and FYM as well as the different levels of fertilizers on the population of soil bacteria, fungi and actinomycetes were very well pronounced at various stages of observations. The highest population of bacteria $\left(35.2 \times 10^{6}\right.$ CFU g ${ }^{-1}$ of soil), fungi $\left(15.9 \times 10^{4} \mathrm{CFU} \mathrm{g}^{-1}\right.$ of soil) and actinomycetes $\left(8.5 \times 10^{3} \mathrm{CFU} \mathrm{g}^{-1}\right.$ of soil) were observed with the application of TDE@1.0 lakh litres ha ${ }^{-1}$ along with 100 per cent RD of NPK fertilizers.

The microbial population got increased from vegetative stage up to flowering stage and subsequently it showed a reduction at postharvest stage. The treatment which received the TDE@1.0 lakh litres ha ${ }^{-1}+100$ per cent RD of NPK fertilizers followed by the application of FYM @ $12.5 \mathrm{t} \mathrm{ha}^{-1}+$ biofertilizers along with 100 per cent RD of NPK fertilizer recorded the highest microbial population. Being more in nutrients and organic material, mainly easily oxidizable and soluble organic carbon, the TDE influence have favorite the proliferation of microbial population during the crop growth by the steady supply of nutrients and accumulation of organic matter in the soil. This was in link with the results of Lakshmanan and Gopal (1996) who described that the sugarcane crop 
irrigated with treated distillery effluent with varying dilutions significantly boosted the microbial population in the root zone soils.

The microbial population was specified to be high in soil irrigated with 50 times dilute effluent. Patil and Shinde (1995) also establish that a high evolution of $\mathrm{CO}_{2}$ in the TDE treated soil due to more microbial activities, same was five times superior than FYM treated soil. Tauk et al., (1990) also give backing for the increased number of fungi, bacteria and actinomycetes due to the treatment of distillery effluent. The deterioration in the microbial activities during the crop growth, generally at harvest was possibly due to the exhaustion of nutrients and organic matter as a result of focused microbial activity and crop uptake during the active stage of crop growth. This result agrees with the results of Valliappan (1998), Goyal et al., (1995) and Murugaragavan (2002) (Table 3).

Table.1 Characteristics of treated distillery effluent

\begin{tabular}{|c|c|c|}
\hline S.No. & Parameters & Values* \\
\hline 1 & Colour & Greenish brown \\
\hline 2 & Specific gravity $\left(\mathrm{g} \mathrm{cm}^{-3}\right)$ & 1.18 \\
\hline 3 & $\mathrm{pH}$ & 7.68 \\
\hline 4 & $\mathrm{EC}\left(\mathrm{dSm}^{-1}\right)$ & 36.4 \\
\hline 5 & $\mathrm{BOD}\left(\mathrm{mg} \mathrm{L}^{-1}\right)$ & 7,890 \\
\hline 6 & $\operatorname{COD}\left(\mathrm{mg} \mathrm{L}^{-1}\right)$ & 38,562 \\
\hline 7 & Total solids $\left(\mathrm{mg} \mathrm{L}^{-1}\right)$ & 51,200 \\
\hline 8 & Total volatile solids $\left(\mathrm{mg} \mathrm{L}^{-1}\right)$ & 23,320 \\
\hline 9 & Total suspended solids $\left(\mathrm{mg} \mathrm{L}^{-1}\right)$ & 5,610 \\
\hline 10 & Total dissolved solids $\left(\mathrm{mg} \mathrm{L}^{-1}\right)$ & 45,590 \\
\hline 11 & Organic carbon $\left(\mathrm{mg} \mathrm{L}^{-1}\right)$ & 28,500 \\
\hline 12 & Total N $\left(\mathrm{mg} \mathrm{L}^{-1}\right)$ & 2000 \\
\hline 13 & Total $\mathrm{P}\left(\mathrm{mg} \mathrm{L}^{-1}\right)$ & 246 \\
\hline 14 & Total $\mathrm{K}\left(\mathrm{mg} \mathrm{L}^{-1}\right)$ & 12,650 \\
\hline 15 & Total Ca $\left(\mathrm{mg} \mathrm{L}^{-1}\right)$ & 2250 \\
\hline 16 & Total $\mathrm{Mg}\left(\mathrm{mg} \mathrm{L}^{-1}\right)$ & 1560 \\
\hline 17 & Total $\mathrm{Na}\left(\mathrm{mg} \mathrm{L}^{-1}\right)$ & 730 \\
\hline 18 & Total $\mathrm{Zn}\left(\mathrm{mg} \mathrm{L}^{-1}\right)$ & 15.7 \\
\hline 19 & Total Fe $\left(\mathrm{mg} \mathrm{L}^{-1}\right)$ & 87.5 \\
\hline 20 & Total $\mathrm{Cu}\left(\mathrm{mg} \mathrm{L}^{-1}\right)$ & 4.95 \\
\hline 21 & Total Mn $\left(\mathrm{mg} \mathrm{L}^{-1}\right)$ & 10.5 \\
\hline 22 & Soluble anions (meq. $\mathrm{L}^{-1}$ ) & \\
\hline 23 & $\mathrm{Cl}^{-}$ & 207 \\
\hline & $\mathrm{SO}_{4}^{2-}$ & 74.6 \\
\hline & $\mathrm{HCO}_{3}^{-}$ & 57.8 \\
\hline & $\mathrm{CO}_{3}^{-}$ & Absent \\
\hline & Soluble cations (meq. $\mathrm{L}^{-1}$ ) & \\
\hline 24 & $\mathrm{~K}^{+}$ & 226 \\
\hline & $\mathrm{Na}^{+}$ & 27.2 \\
\hline & $\mathrm{Ca}^{2+}$ & 48.3 \\
\hline & $\mathrm{Mg}^{2+}$ & 50.8 \\
\hline & SAR & 3.86 \\
\hline 25 & RSC (meq. $\mathrm{L}^{-1}$ ) & -41.3 \\
\hline 26 & SSP & 7.71 \\
\hline 27 & PS (meq. $\left.\mathrm{L}^{-1}\right)$ & 245 \\
\hline 28 & Microbial Population & \\
\hline & Bacteria (x $\left.10^{6} \mathrm{CFU} \mathrm{ml}^{-1}\right)$ & 3.5 \\
\hline 29 & 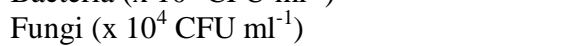 & 12.2 \\
\hline 30 & Actinomycetes $\left(\mathrm{x} 10^{2} \mathrm{CFU} \mathrm{ml} \mathrm{H}^{-1}\right)$ & 3.5 \\
\hline
\end{tabular}

*Mean of two samples 
Table.2 Characteristics of biocompost

\begin{tabular}{|c|c|c|}
\hline Parameters & & Biocompost* \\
\hline $\mathrm{pH}$ & - & 7.56 \\
\hline Electrical conductivity(1:2.5) & $\mathrm{dS} \mathrm{m}^{-1}$ & 6.74 \\
\hline Organic carbon & per cent & 21.9 \\
\hline Total Nitrogen & per cent & 1.58 \\
\hline Total Phosphorus & per cent & 2.32 \\
\hline Total Potassium & per cent & 4.56 \\
\hline Total Calcium & per cent & 3.68 \\
\hline Total Magnesium & per cent & 2.29 \\
\hline Total sodium & per cent & 1.56 \\
\hline $\mathrm{C}: \mathrm{N}$ ratio & - & 20.4 \\
\hline Iron & $\mathrm{mg} \mathrm{kg}^{-1}$ & 396 \\
\hline Zinc & $\mathrm{mg} \mathrm{kg}^{-1}$ & 87 \\
\hline Copper & $\mathrm{mg} \mathrm{kg}^{-1}$ & 41 \\
\hline Manganese & $\mathrm{mg} \mathrm{kg}^{-1}$ & 410 \\
\hline Cadmium & $\mathrm{mg} \mathrm{kg}^{-1}$ & $2-10$ \\
\hline Lead & $\mathrm{mg} \mathrm{kg}^{-1}$ & $21-28$ \\
\hline Nickel & $\mathrm{mg} \mathrm{kg}^{-1}$ & $10-12$ \\
\hline Chromium & $\mathrm{mg} \mathrm{kg}^{-1}$ & $2-4$ \\
\hline Bacteria & $\left(\times 10^{6} \mathrm{CFU} \mathrm{g}^{-1}\right.$ of soil $)$ & 9.9 \\
\hline Fungi & $\left(\times 10^{4} \mathrm{CFU} \mathrm{g}^{-1}\right.$ of soil $)$ & 33.5 \\
\hline Actinomycetes & $\left(\times 10^{2} \mathrm{CFU} \mathrm{g}^{-1}\right.$ of soil $)$ & 8.8 \\
\hline Dehydrogenase & $\mu \mathrm{g}$ of $\mathrm{TPF} \mathrm{g}^{-1}$ of soil & 10.3 \\
\hline Phosphatase & $\mu \mathrm{g}$ of PNPP $\mathrm{g}^{-1}$ of soil & 18.9 \\
\hline Urease & $\mu \mathrm{g} \mathrm{NH}_{4}-\mathrm{N} \mathrm{g}^{-1}$ of soil $\mathrm{h}^{-1}$ & 8.4 \\
\hline
\end{tabular}

*Mean of three samples 


\section{Int.J.Curr.Microbiol.App.Sci (2017) 6(12): 1334-1348}

Table.3 Effect of TDE, biocompost and FYM on soil bacterial and fungal population at various stages of maize crop

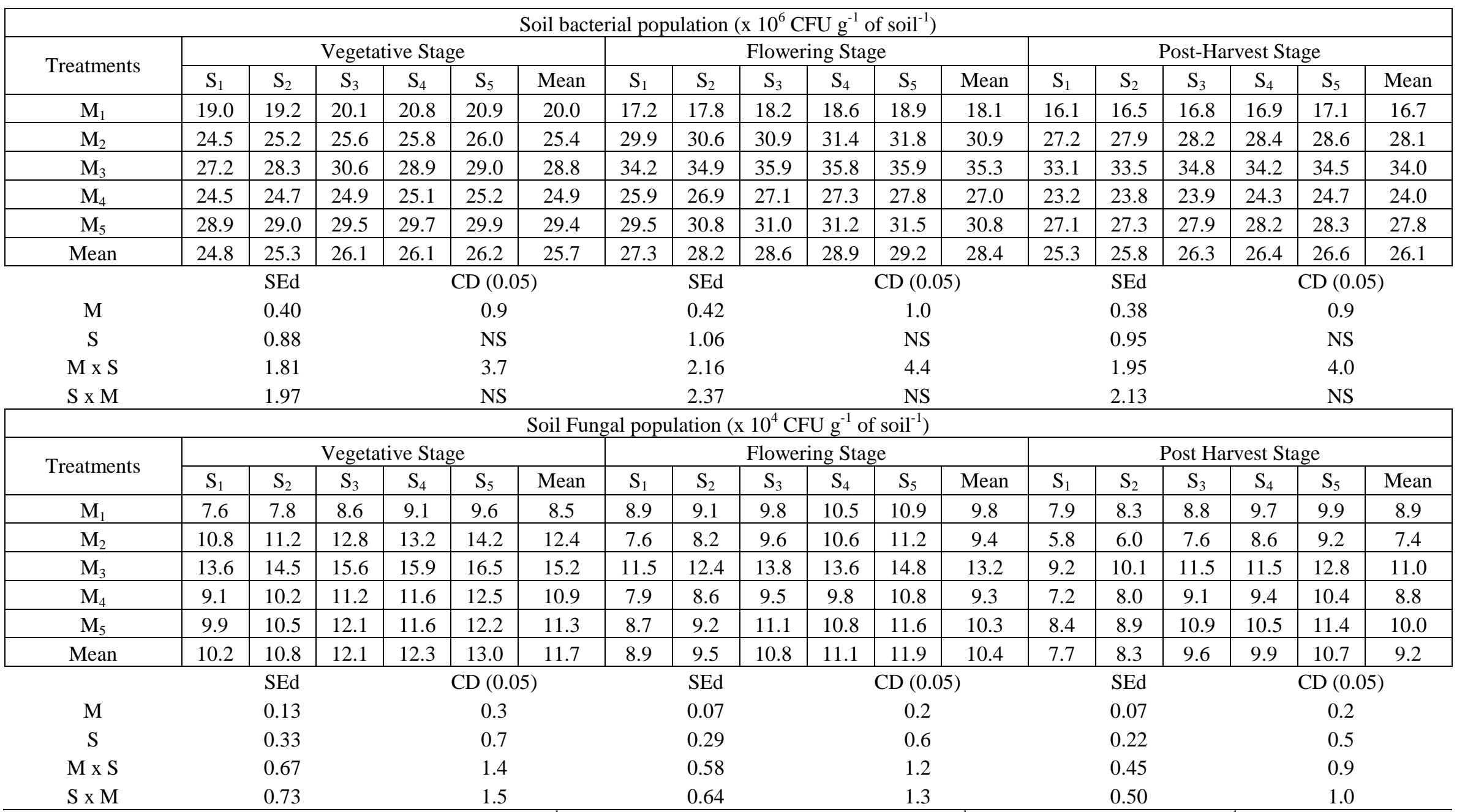

M1 - Contorl; M2 - application of TDE @ 0.5 lakh litres ha ${ }^{-1}$; M3 - application of TDE @ 1.0 lakh litres ha ${ }^{-1}$; M4 - Bio - compost @ 5 t ha ${ }^{-1}$; M5 - FYM @ 12.5 t $\mathrm{ha}^{-1}+$ Biofertilizers

$\mathrm{S}_{1}$ - Control; $\mathrm{S}_{2}-50 \%$ RD of $\mathrm{N}$ and $\mathrm{P}_{2} \mathrm{O}_{5} ; \mathrm{S}_{3}-75 \%$ RD of $\mathrm{N}$ and $\mathrm{P}_{2} \mathrm{O}_{5} ; \mathrm{S}_{4}-100 \% \mathrm{RD}$ of $\mathrm{N}$ and $\mathrm{P}_{2} \mathrm{O}_{5} ; \mathrm{S}_{5}-100 \% \mathrm{RD}$ of $\mathrm{NPK}$ :

All values are mean of three replications 
Table.4 Effect of TDE, biocompost and FYM on soil phosphatase and urease activities at various stages of maize crop

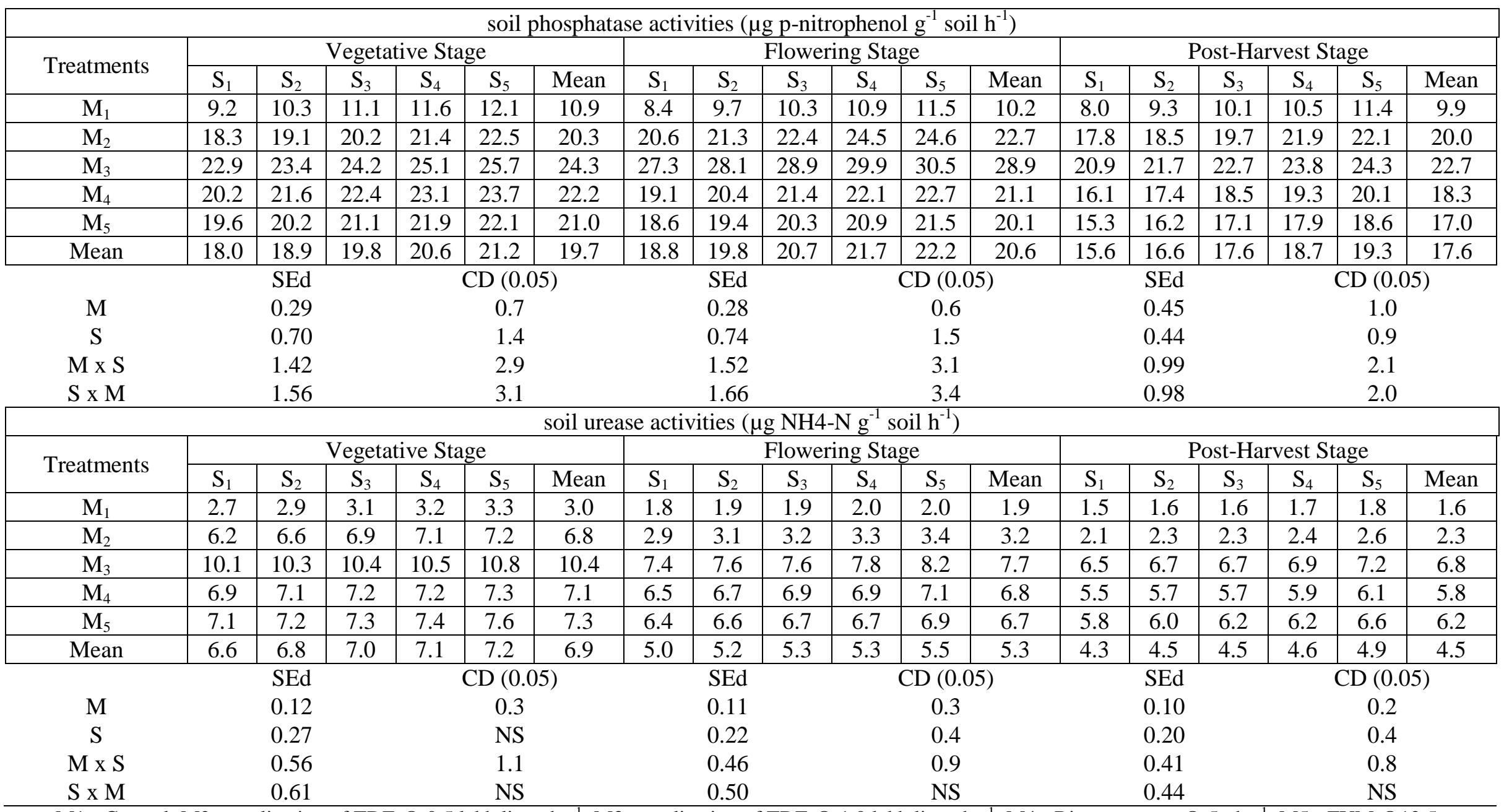

M1 - Control; M2 - application of TDE @ 0.5 lakh litres ha $^{-1}$; M3 - application of TDE @ 1.0 lakh litres ha ${ }^{-1}$; M4 - Bio - compost @ 5 t ha ${ }^{-1}$; M5 - FYM @ 12.5 t ha $^{-1}+$ Biofertilizers

$\mathrm{S}_{1}$ - Control; $\mathrm{S}_{2}-50 \% \mathrm{RD}$ of $\mathrm{N}$ and $\mathrm{P}_{2} \mathrm{O}_{5} ; \mathrm{S}_{3}-75 \% \mathrm{RD}$ of $\mathrm{N}$ and $\mathrm{P}_{2} \mathrm{O}_{5} ; \mathrm{S}_{4}-100 \% \mathrm{RD}$ of $\mathrm{N}$ and $\mathrm{P}_{2} \mathrm{O}_{5} ; \mathrm{S}_{5}-100 \% \mathrm{RD}$ of NPK:

All values are mean of three replications 
Fig.1 Effect of treated distillery effluent, BC and FYM on soil actinomycetes population at various stages of maize crop

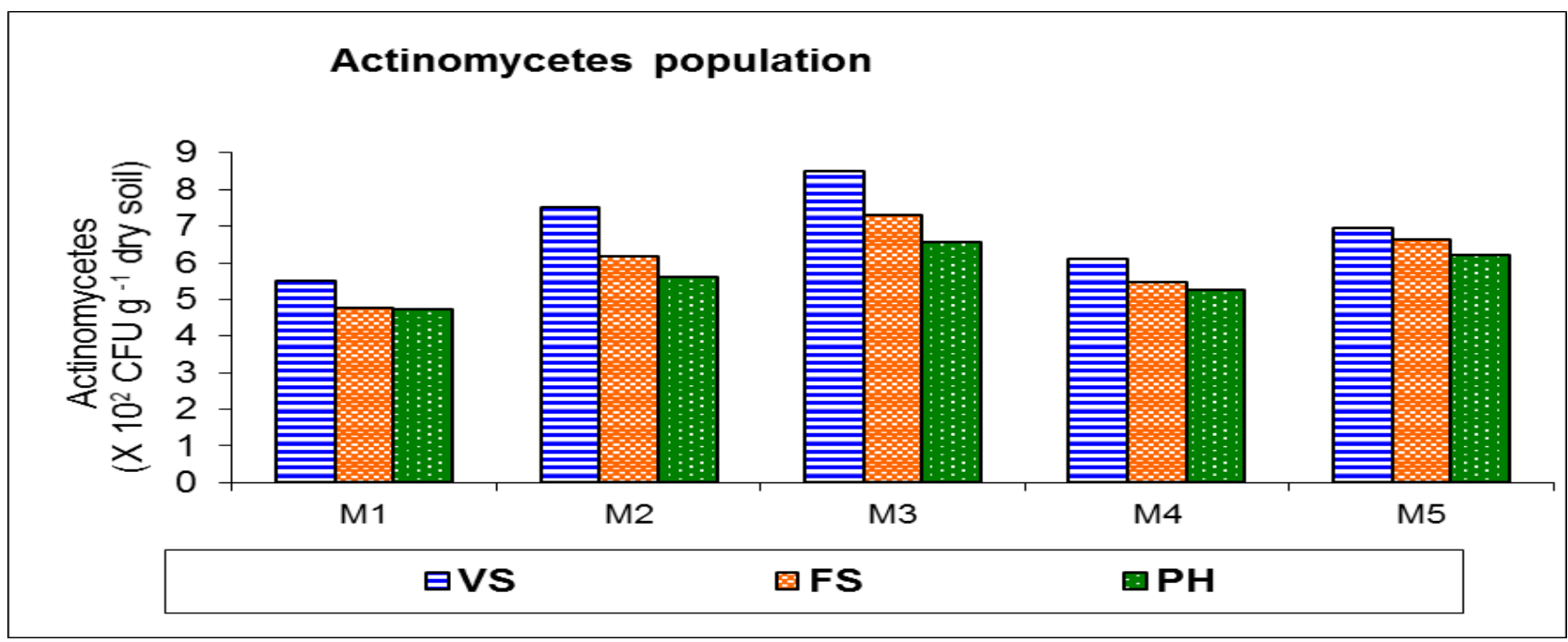

Fig.2 Effect of treated distillery effluent, BC and FYM on soil dehydrogenase activities at various stages of maize crop

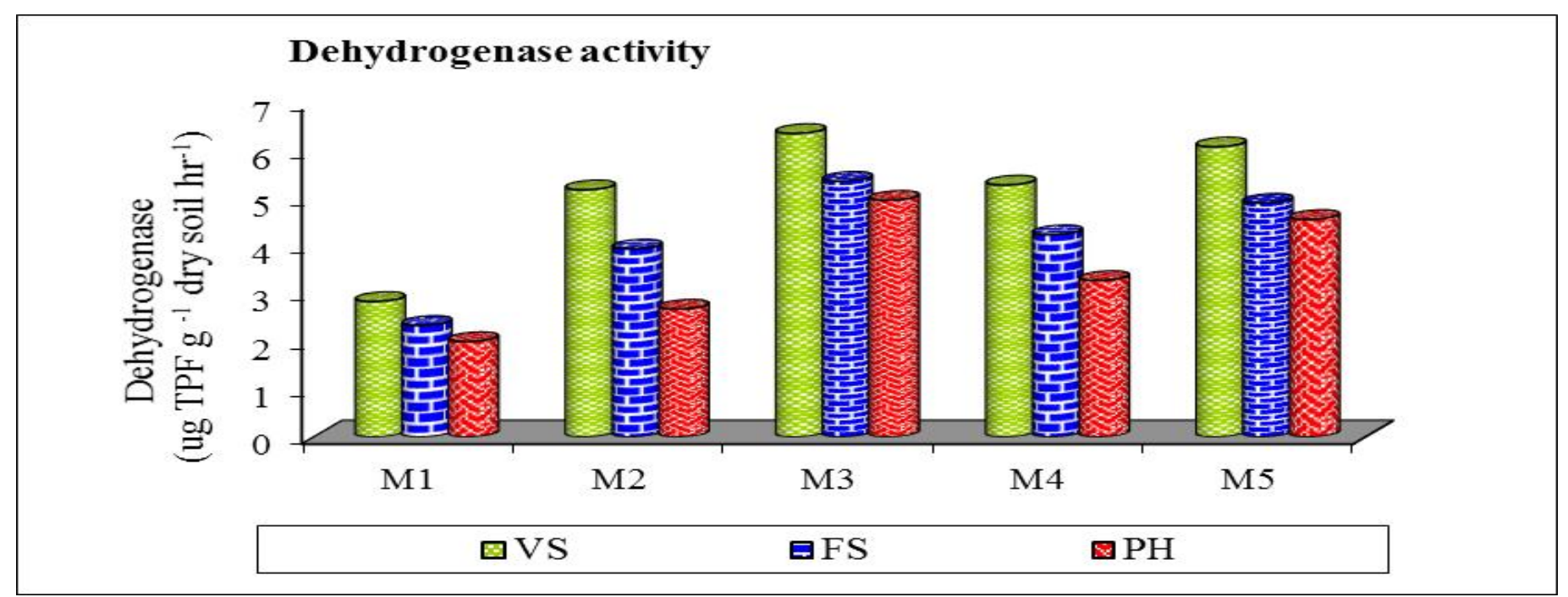




\section{Soil enzyme activities}

\section{Soil dehydrogenase activity}

The soil dehydrogenase activity was observed at different stages of the crop growth under various treatments ranged from 1.8 to $6.9 \mu \mathrm{g}$ TPF $\mathrm{g}^{-1}$ dry soil $\mathrm{hr}^{-1}$ in red sandy loam soil. Application of TDE as well as organic manures significantly increased the dehydrogenase activity of soils. The highest mean value of soil dehydrogenase activity ranged from 5.0 to $6.4 \mu \mathrm{g}$ TPF g ${ }^{-1}$ dry soil $\mathrm{hr}^{-1}$ in under TDE application @ 1.0 lakh litres ha 1 and again it was superior to the rest of the main plot at all the stages of observation.

The impact of organic manures application was found significant. Application of FYM @ $12.5 \mathrm{t} \mathrm{ha}^{-1}+$ biofertilizers and bio-compost @ $5 \mathrm{t} \mathrm{ha}^{-1}$ are comparable at all the stages of observation and recorded higher level of soil dehydrogenase activity than control.

Among the subplot treatments, application of 100 per cent RD of NPK fertilizers is comparable with the application of 100 per cent recommended dose of NP fertilizer without $\mathrm{K}$ and higher soil dehydrogenase activity recorded in red sandy loam soil (3.9 $5.6 \mu \mathrm{g} \mathrm{TPF} \mathrm{g}^{-1}$ dry soil $\mathrm{hr}^{-1}$ ) which were found to be superior to other subplot treatments at most of the stages of observations (Fig. 2).

The interaction effect of main and subplot was significant at all the stages. Application of TDE @ 1.0 lakh litres ha ${ }^{-1}$ along with 100 per cent RD of NPK fertilizer is comparable with TDE@1.0 lakh litres ha ${ }^{-1}$ along with 100 per cent RD of NP fertilizer as well as the application of 75 per cent RD of NP fertilizer recorded higher dehydrogenase activity in soils than the rest of treatment combinations at all the stages of observations. In general, the soil dehydrogenase activity was gradually decreased with advancement crop growth.

\section{Soil urease activity}

The urease activity of the soil monitored at different stages of the crop growth under various treatments and it ranged from 1.5 to $10.8 \mu \mathrm{g} \mathrm{NH}_{4}-\mathrm{N} \mathrm{g}^{-1}$ dry soil $\mathrm{hr}^{-1}$ in sandy loam soil. Application of TDE and organic manures significantly increased the urease activity of soil at all the stages of observation. The highest urease activity among different growth stages ranged from 6.8 to $10.4 \mu \mathrm{g}$ $\mathrm{NH}_{4}-\mathrm{N} \mathrm{g}^{-1}$ dry soil $\mathrm{hr}^{-1}$ was recorded in treatment which received TDE 1.0 lakh litres $\mathrm{ha}^{-1}$ at all the stages of observations and it was superior to the rest of the main plot treatments.

The effect of organic manures application on soil urease activity was found significant over control. Application of FYM @ $12.5 \mathrm{t} \mathrm{ha}^{-1}+$ biofertilizers recorded higher urease activity followed by biocompost @ $5 \mathrm{t} \mathrm{ha}^{-1}$ in almost all the stages of crop, but are comparable.

With respect to the subplot treatments, application of 100 per cent RD of NPK fertilizers recorded higher urease activity (4.9 to $7.2 \mu \mathrm{g} \mathrm{NH}_{4}-\mathrm{N} \mathrm{g}^{-1}$ dry soil $\mathrm{hr}^{-1}$ ) which is comparable with 100 per cent RD of NP fertilizer which was found to be superior to other subplot treatments observed in all the stages of crop except vegetative stage.

The interaction effect was significant at all the stages. Application of TDE @ 1.0 lakh litre $\mathrm{ha}^{-1}$ along with 100 per cent RD of NPK fertilizer is comparable with the application of TDE @ 1.0 lakh litres ha ${ }^{-1}$ along with 100 per cent RD of NP fertilizers as well as the application of 75 per cent RD of NP fertilizer $\left(\mathrm{M}_{3} \mathrm{~S}_{3}\right)$ recorded higher soil urease activity than the rest of the treatment combinations at all the stages of observations.

The soil urease activity gradually decreased with advancement crop growth 


\section{Soil phosphatase activity}

The phosphatase activity of the soil monitored at different stages of the crop growth under various treatments ranged from 8.0 to $25.7 \mu \mathrm{g}$ p-nitro phenol $\mathrm{g}^{-1}$ of dry soil $\mathrm{hr}^{-1}$. Application of TDE and organic manures significantly increased the soil phosphatase activity at all the growth stages of the crop over control. The highest mean value of phosphatase activity in different growth stages varied between 22.9 to $28.9 \mu \mathrm{g}$ p-nitro phenol g ${ }^{-1}$ of dry soil $\mathrm{hr}^{-1}$ under the treatment of TDE @ 1.0 lakh litres $\mathrm{ha}^{-1}$ and found superior to the rest of the treatments (Table 4).

The impact of organic manures application recorded significant variation among them. Application of bio-compost @ $\mathrm{t} \mathrm{ha}^{-1}$ recorded higher level of soil phosphatase activity compared to the standard practice of applying FYM @ $12.5 \mathrm{t} \mathrm{ha}^{-1}+$ biofertilizers $\left(\mathrm{M}_{5}\right)$ in almost of the growth stages of crop; It was observed that application of 100 per cent RD of NPK fertilizer recorded the higher phosphatase activity (19.3 to $22.2 \mu \mathrm{g}$ p-nitro phenol g $\mathrm{g}^{-1}$ of dry soil $\mathrm{hr}^{-1}$ ) which was superior to other subplot treatments at all the growth stages of the crop and it was on par with 100 per cent RD of NP fertilizer application.

The interaction effect on $\mathrm{M} \times \mathrm{S}$ was significant at all the stages. Application of TDE @ 1.0 lakh litres ha ${ }^{-1}$ along with 100 per cent RD of NPK fertilizers recorded the higher phosphatase activity in soil than the rest of the treatment combinations at all the stages of crop and it was on par with TDE @ 1.0 lakh litres ha ${ }^{-1}$ along with 100 per cent RD of NP fertilizers as well as the application of 75 per cent RD of NP fertilizers. In general, the soil phosphatase activity was gradually decreased with advancement crop growth except TDE applied plot wherein flowering stage recorded higher phosphatase activity than other stages.
Enzyme activity in soil supports the oxidation-reduction reaction and nutrient transformations. In the present investigation, greater activities of dehydrogenase, urease and phosphatase were supplementary with the TDE application. The treatment that received the TDE @ 1.0 lakh litres ha ${ }^{-1}+100$ per cent RD of NPK fertilizers supported greater enzyme activities followed by the application of FYM @ $12.5 \mathrm{t} \mathrm{ha}^{-1}$ along with 100 per cent RD of NPK fertilizer and TDE @1.0 lakh litres $\mathrm{ha}^{-1}+100$ per cent RD of NP fertilizers compared to control. The TDE being liquid organic manure, increased the organic matter and nutrients content of the soil and subsequently enhanced the microbial activities. The high dose of TDE along with the recommended dose of NPK recorded the highest activities. It implies that organic and inorganic nutrient inputs provided a nutrient rich environment, which is essential for the development of microbes and synthesis of enzymes (Kamalakumari and Singaram, 1995).

Engracia Madejon et al., (2003) establish a positive association between the organic residues and dehydrogenase, $\beta$-glucosidase, urease and protease activities of the soil. Ramana et al., (2002) also stated that the enzyme activities were increased due to the application of distillery effluent.

Organic manure adding was found to improve the microbial activities which in turn preferred the synthesis of various enzymes in soil (Dinesh et al., 2000). Above mentioned three enzymes show a substantial part in the bio-transformation of nutrients in soil, and thus effect the nutrients availability in soil and uptake through crops. Phosphatase hydrolyze organic $\mathrm{P}$ to inorganic $\mathrm{P}$ and catalyze the rate limiting steps of $\mathrm{P}$ nutrient cycling and therefore, phosphatase activity plays an important role in $\mathrm{P}$ availability to plants from native organic $\mathrm{P}$ compounds. The phosphatase 
activity, thus, can be a worthy indicator of the organic $\mathrm{P}$ mineralization potential and biological activity of soils (Dick and Tabatabai, 1993). The mineralization rate of organic $\mathrm{P}$ is appropriate to both $\mathrm{P}$ nutrition of crops and phosphatase activity in soil. Therefore, advanced enzyme activities in soil recommended that the mineralization of $\mathrm{N}$ and $\mathrm{P}$ was superior due to the application of Treated Distillery Effluent. Parallel result was reported by Rajannan et al., (1998).

The soil microbial population has found to be increased with the application of TDE over control. The soil bacterial population recorded the highest value of 20.1 and $19.3 \times 10^{6} \mathrm{CFU}$ $\mathrm{g}^{-1}$ of soil with the application of TDE @ 1.0 lakh litres ha $^{-1}$ compared to control at postharvest stage. There was an increase in the fungal population to the tune of 30.3 per cent over control at post-harvest stage. Application of TDE @ 1.0 lakh litres ha ${ }^{-1}$ recorded the highest actinomycetes population at all stages of crop growth. Similarly the enzyme viz., Dehydrogenase, Phosphatase and Urease activity of the soil was significantly influenced by the application of TDE and also due to the addition of organic amendments.

\section{Acknowledgement}

This research was facilitated by Department of Soil Science \& Agricultural Chemistry, Tamil Nadu Agricultural University; Coimbatore carried out under the direct supervision of Prof. V. Velu, former Special Officer (DNRM), TNAU, Coimbatore -3.

\section{References}

Anon. 2010, Annual Progress Report- Kharif 2010, All India Coordinated Research Project- Maize, Project Directors Report. R. Sai Kumar, Directorate of Maize Research, PUSA Campus, New Delhi.

Baskar, M., C. Kayalvizhi and M. Subash Chandra Bose.2003. Eco-friendly utilisation of distillery effluent in Agriculture - a review. Agric. Rev., 24(1): 16 - 30.

Bremner, J.M and R.L. Mulvany. 1978. Urease activity in soils. In: Soil enzymes. (Ed.) R.G. Burns, Academic press, New York, USA, pp.149-196.

Chendrayan, K., T.K. Adhya and N. Sethunathan. 1980. Assay of dehydrogenase activity in soils. Soil Biol. Biochem., 12: 271-273.

Das, Madhumita, Chakraborty, H., Singandhupe, R.B., Muduli, S.D. and Kumar, A. (2010). Utilization of distillery wastewater for improving production in unproductive paddy growing area of India. Journal of Scientific and Industrial Research, 69:56063.

Dick,W.A and M.A. Tabatabai. (1993). Significance and potential uses of soil enzymes. In: Soil microbial ecology: Application in agricultural and environmental management. Meeting, F.B. (ed.), Marcel Dekker, New York, pp. 95125.

Dinesh, R., R.P. Dubey, A.N. Ganeshamurthy and G. Shyam Prasad. (2000). Organic manuring in rice-based cropping system: Effects on soil microbial biomass and selected enzyme activities. Curr. Sci., 79: 1716-1720.

Directorate of Maize Research, (2008). Salient achievements of AICRP maize. Directorate of Maize Research, New Delhi, India

Engracia Madejon, S., P. Burgos, R, Lopez and F. Cabrera. (2003). Agricultural use of three organic residues: effect on orange production and on properties of a soil of Spain. Nutr. Cycl. Agroecosyst., 65: 281288

Gomez, K. A. and Gomez, A. A. (1984). Statistical procedure for Agricultural Research. An International Rice research Institute Book. A Wiley-Interscience Publication, J. Wiley and Sons, Inc.

Goyal, S., K. Chander, K. K. Kapoor. (1995) Effect of distillery waste water application on soil microbial properties and plant growth. Environ. Eco., 13 (1): 89 - 93.

Joshi H C, Pathak H, Chaudhary A, Joshi T P, Phogat V K and Kalra N, (2000). Changes in soil properties with distillery effluent irrigation, J Envir on Res, 6 153-162. 
Kamalakumari, K. and P. Singaram. (1995). Relationship among soil chemical, biochemical properties and enzyme activities. Madras Agric. J., 82: 69-70.

Lakshmanan, A., N. O. Gopal. Effect of distillery effluent irrigation on the microbial population of the soil. (1996). In: Proc. Nat. Sym. on use of distillery and sugar industry wastes in agriculture, ADAC \& RI (TNAU), Trichirappali. p. 5.

Mohamed Haroon, A. M. Subash Chandra Bose. (2004). Use of distillery spentwash for alkali soil reclamation, treated distillery effluent for fertigation of crops. Indian farm., 53(11): 48 - 51.

Murugaragavan, R.. Distillery spentwash on crop production in dryland soils. M.Sc. Thesis, Tamil Nadu Agric. Univ., Coimbatore. 2002.

Patil. G. D and Shinde. 1995. Effect of spentwash (distillery effluent), spentwash slurry and pressmud compost in maize. J. Indian Soc. Soil. Sci., 43(4): 700-702.

Rajannan, G., L. Devarajan and G. Oblisami. (1998). Impact of distillery effluent irrigation on growth of banana crop. In: Proc. Nat. Sem. on application of treated effluent for irrigation held at REC, Tiruchirapalli, Mar. 23, p. 56.

Ramana, S., A. K. Biswas and A.B Singh. (2002). Effect of distillery effluents on some physiological aspects in maize. Biores. Technol., 84(3): 295-297.

Seshaiah, M. P. (2000). Sorghum grain in poultry feed. In: Technical and Institutional options for sorghum grain mould management; Proc.Intl. Consultation, Chandrasekaran, A., R. Bundyopadhyay and H.I. Hall (Eds.). ICRISAT, Petencheru, Andhra Pradesh,
India, 18-19 May 2000. pp. 240-241.

Shoichi Ito. (2006). World corn statistics and graphics. http://www. Worldfood.apionet. or.jg/graph/num/cgi

Sukanya, TS, Meli, SS and Patil, RH, (2002). Effect of spent wash asirrigation water on performance of maize (Zea mays) and soil fertility, Indian J Agric Sci 72; 73-78.

Tabatabai, M.A and M.J. Bremner. (1969). Use of p-nitrophenol phosphate for assay of soil phosphatase activity. Soil Biol. Biochem., 1: 301-307.

Tamil Nadu Agricultural University, Crop Production Guide (TNAU CPG) (2007). Crop Production Guide, Tamil Nadu agricultural University, TNAU Press, Coimbatore-3.

Tauk, S. M., I. H. Schoenlein Crusius and A. Petenate.. (1990). Ecological model of nutrients, microorganisms and enzymatic activity of soil in a cerrado are treated with vinasse, corumbati. Reviste de Microbiologia., 1: 99 - 108.

Uppal, J.. Waste utilization and effluent treatment in the Indian alcohol industry-an overview. In: Proceedings of Indo-EU workshop on promoting efficient water use in agro-based industries, New Delhi, (2004). Jan 15-16. pp.12-15.

Valliappan, K. Recycling of distillery spent washAn eco-friendly effective reclamation technology for sodic soils. Ph.D. Thesis, Tamil Nadu Agricultural University. (1998). Coimbatore, India.

Waksman, S. A. and E. B. Fred. (1922). A tentative outline of the plate method for determining the number of microorganisms in soil. Soil Sci., 14: 27 - 28.

\section{How to cite this article:}

Dhakshanamoorthy Dinesh, Lakshmanan Chithra, Murugaiyan Baskar, Karuppusamy Rajan, Kandasamy Senthilraja, Mariappan Sankar, Raj Kumar and Karthikeyan Sivakumar. 2017. Variation of Soil Microbial Growth and Enzyme Activities by Application of Treated Distillery Effluent in Maize Crop Grown Under Sandy Loam Soils. Int.J.Curr.Microbiol.App.Sci. 6(12): 1334-1348. doi: https://doi.org/10.20546/ijcmas.2017.612.151 